Журнал «Герспективита інновації наукњ

(Серія«Гедагогіка», Серія«Гцихологія», Серія«Медицинв»

№4(4) 2021

УДК 372.851:373.31.001.895

https://doi.org/10.52058/2786-4952-2021-4(4)-96-105

Вінтоняк Оксана Василівна кандидат філологічних наук, викладач кафедри педагогіки та методик навчання освітніх галузей і технологій початкової освіти, Коломийський педагогічний фаховий коледж Івано-Франківської обласної ради, вул. Івана Франка, 12, м. Коломия, 78200, e-mail:-oksana/zv@ukr.net, https://orcid.org/0000-0003-0040-3582

Степаненко Олена Костянтинівна кандидат філологічних наук, доцент, доцент кафедри соціально-гуманітарної освіти, Комунальний заклад вищої освіти «Дніпровська академія неперервної освіти» Дніпропетровської обласної ради», вул. Володимира Антоновича, 70, м. Дніпро, 49006, e-mail: olena.step@ukr.net, https://orcid.org/0000-0003-0887-5808

Чикалова Тетяна Григорівна кандидат педагогічних наук, старший викладач, Комунальний вищий навчальний заклад «Херсонська академія неперервної освіти» Херсонської обласної ради, вул. Покришева, 41, м. Херсон, 73034, e-mail: chik.tetyana@ukr.net, https://orcid.org/0000-0001-8687-3176

\title{
ДОСВІД ВИКОРИСТАННЯ ІННОВАЦІЙНИХ ТЕХНОЛОГІЙ У ПОЧАТКОВІЙ ШКОЛІ
}

Анотація. В статті розкрито особливості застосування інноваційних методів навчання молодших школярів. Подано коротку характеристику видів інноваційних технологій, що використовуються у початковій освіті, зокрема особливу увагу приділено платформам, які можуть бути використані при дистанційній формі навчання. Визначено сучасні тенденції в освітній галузі, які прослідковуються внаслідок активного використання інноваційних технологій у навчальному процесі. Оцінено основні фактори, вплив яких позначається на рівні якості надання освіти молодшим школярам. Відзначено, що новітні освітні технології покликані знівелювати різницю між соціальним і економічним становищем різних верств населення і країн з різним рівнем розвитку економіки. Визначено перелік умов, за яких треба вдаватися до використання різних технологій навчання. Проведено співставлення змін, які відбуваються в сучасній освіті, зокрема вказано на необхідність чіткого усвідомлення особливостей нових видів навчання порівняно із традиційним. Наголошено, що під час навчального процесу та оцінювання за допомогою нових технологій педагоги не відмовляються від зобов'язань перед здобувачами освіти та проводять роботу 3 ними, надаючи допомогу у розробці стратегії навчання та оцінювання, здійснюють всебічну підтримку, можуть при цьому виступати у ролі 
наставників, тьюторів. Розкрито переваги нових технологій освіти. Основна увага в статті зосереджується на характеристиці засобів налагодження взаємодії 3 дітьми під час використання новітніх засобів навчання, зокрема, тематичних блогів, форумів, чатів. Здійснено характеристику спеціальних освітніх ресурсів та додатків. Розглянуто види та критерії оцінювання рівня знань, що були отримані в результаті нових технологій навчання. Висвітлено нові завдання, які ставляться перед педагогами в процесі використання інноваційних технологій. Встановлено, що після вивчення будь-якої навчальної дисципліни, здобувач освіти має чітко усвідомлювати, які саме навички та компетентності він здобув. 3'ясовано, що ефективне використання інноваційних методів $є$ одним із засобів, що надає можливість відслідкувати всі слабкі та сильні сторони, визначити прогалини в знаннях та здійснити рефлексію. Виокремлено основні тенденції впровадження інноваційних технологій у закладах початкової освіти в Україні.

Ключові слова: новітні методи, інтернет, інноваційні технології, розвиток початкової освіти, нові засоби навчання в початковій школі.

Vintoniak Oksana Vasylivna Candidate of Philological Sciences, teacher of the department of pedagogy and methods of teaching educational branches and technologies of primary education, Kolomyia Pedagogical Proffecional College of the Ivano-Frankivsk Regional Council, Ivan Franko St., 12, Kolomyia, 78200, e-mail: oksana/zv@ukr.net, https://orcid.org/0000-0003-0040-3582

Stepanenko Olena Kostiantynivna Candidate of Philological Sciences, Associate Professor, Associate Professor at the Department of Social and Humanitarian Education, Communal Institution of Higher Education «Dnipro Academy of Continuing Education» of Dnipropetrovsk Regional Council, Vladimir Antonovich St., 70, Dnipro, 49006, e-mail: olena.step@ukr.net, https://orcid.org/0000-0003-0887-5808

Chykalova Tetiana Grigorivna Candidate of Pedagogical Science, Senior lecturer, Municipal higher educational institution «Kherson Academy of Continuing Education» of Kherson regional council, Pokrisheva St., 41, Kherson, 73034, e-mail: chik.tetyana@ukr.net, https://orcid.org/0000-0001-8687-3176

\section{EXPERIENCE OF USING INNOVATIVE TECHNOLOGIES IN PRIMARY SCHOOL}

Abstract. The article reveals the peculiarities of the application of innovative teaching methods for primary school children. A brief description of the types of innovative technologies used in primary education is given, in particular, special attention is paid to platforms that can be used in distance learning. The current trends in the field of education, which are traced due to the active use of innovative 
technologies in the educational process, are identified. The main factors whose impact affects the level of quality of education for primary school students are assessed. It is noted that the latest educational technologies are designed to eliminate the difference between the social and economic situation of different segments of the population and countries with different levels of economic development. The list of conditions under which it is necessary to resort to use of various technologies of training is defined. A comparison of the changes taking place in modern education is made, in particular, the need for a clear understanding of the features of new types of education compared to traditional education is pointed out. It is emphasized that during the educational process and assessment with the help of new technologies, teachers do not waive their obligations to students and work with them, assisting in the development of teaching and assessment strategies, provide comprehensive support, and can act as mentors, tutors. The advantages of new educational technologies are revealed. The main focus of the article is on the characteristics of the means of establishing interaction with children when using the latest learning tools, in particular, thematic blogs, forums, chats. The characteristic of special educational resources and applications is carried out. The types and criteria for assessing the level of knowledge obtained as a result of new learning technologies are considered. The new tasks set for teachers in the process of using innovative technologies are highlighted. It is established that after studying any discipline, the student must clearly understand what skills and competencies he has acquired. It has been found that the effective use of innovative methods is one of the tools that allows you to track all the weaknesses and strengths, identify gaps in knowledge and reflect. The main trends in the introduction of innovative technologies in primary education in Ukraine are highlighted.

Keywords: newest methods, internet, innovative technologies, development of primary education, new means of teaching in primary school.

Постановка проблеми. Національною доктриною розвитку освіти в Україні прийнято стратегію прискореного, випереджаючого, інноваційного розвитку початкової освіти, забезпечення самоствердження і самореалізації дитини молодшого шкільного віку. Однією 3 умов формування Нової української школи є впровадження в освітній процес інноваційних методів, що оптимізують процес удосконалення освіти [1].

Зазначені вище аспекти актуалізовано документами, які регламентують сучасну освіту, а саме Державним стандартом початкової загальної освіти (2018р.), Професійним стандартом «Вчитель початкових класів закладу загальної середньої освіти» (2018р.), Національною доктриною розвитку освіти (2002 р.), Національною стратегією розвитку освіти в Україні на період до 2021 року (2013 р.), Державною програмою «Вчитель» (2002р.), Галузевою концепцією розвитку неперервної педагогічної освіти (2013р.), Концепцією реалізації державної політики у сфері реформування загальної середньої освіти «Нова українська школа» на період до 2029 року (2016 р.), Законом України «Про освіту» (2017 р.). 
Необхідність забезпечення високого наукового рівня навчання, розвитку пізнавальних інтересів та творчих навичок учнів, прискорення темпів вивчення навчальних матеріалів робить актуальною проблему забезпечення освітнього середовища загалом та навчальних закладів зокрема високоякісними джерелами інформації та комунікаційних технологій [2].

Аналіз останніх досліджень і публікацій. Останнім часом проблемі використання новітніх технологій навчання в початковій школі приділяється велика увага в науковій літературі. Розробки різноманітних інструментів навчання $\epsilon$ предметом роботи багатьох учених, тому тенденції, що прослідковуються останнім часом в Україні і світі, дозволяють зробити висновок про суттєве збільшення активності роботи науковців у цьому напрямку. Можна виокремити теоретичні, методологічні та методичні напрацювання в сфері технологічного забезпечення навчального процесу таких науковців, як В. Кухаренка, С. Вітвицької, В. Ясулайтіса та багато інших.

На сьогодні існує багато підходів до визначення проблем та переваг у застосуванні різних технологій навчання. Це питання було вивчене такими вченими, як М. Томпсон, М. Мур, А. Кларк, і Д. Кіган. Кожен із цих авторів підкреслював окремі аспекти новітніх методів навчання [3].

Мета статті $\epsilon$ визначення особливостей та оцінка досвіду впровадження сучасних інноваційних методів та прийомів навчання у початковій школі.

Виклад основного матеріалу. Враховуючи різні особливості в розвитку дітей нового покоління, слід переглядати підходи у навчанні, розробляти нові методи, використовувати нові засоби навчання та розширювати компетентності вчителів, яким необхідно працювати зі школярами. Педагог в наш час вже не $\epsilon$ просто носієм знань, про які він повинен просто розповісти дитині, як це було раніше. Головне завдання педагогічного працівника - мотивація дітей з метою формування у них ініціативи та самостійності мислення. Педагог в сучасному освітньому процесі - організатор індивідуальної та групової діяльності здобувачів освіти, де кожен з них може досягти реалізації своїх здібностей та задоволення власних інтересів. Учитель повинен створити умови, якісне розвивальне середовище з використанням ЕОР, де стає можливим ефективний розвиток особистості, продуктивний процес здобування знань та вмінь, які $\epsilon$ необхідними для успішного життя в сучасному інформаційному світі.

Особливості розвитку молодших школярів та зміни в суспільстві не можуть не відбиватись на вимогах до організації сучасного освітнього процесу. В умовах інформатизації суспільства та цифровізації освіти гостро стоїть питання щодо використання інформаційно-комп`ютерних технологій, починаючи з початкової школи. Введення раннього вивчення новітніх технологій в освітній процес обумовлено вимогами нового державного освітнього стандарту початкової загальної освіти [2].

Сучасні методи і методичні прийоми навчання були створені і вироблені протягом багатьох віків, саме тому для педагогів сьогодні необхідно всебічно 
Журнал«Герспектвиитаіноовації наукиљ

(Серія«Гедагогіка», Серія«Гцихологія», Серія«Медицинв»

№4(4) 2021

аналізувати усю систему методів, що використовується для вивченні предмета, виявлення не використаних поки що резервів, а також для успішного вирішення завдань, що виникають у навчальному процесі.

Передусім варто зазначити, що методи навчання $є$ складною педагогічною категорією. Завдяки цим методам відбувається виконання основних функцій навчального процесу: освітньої, виховної, розвивальної, спонукальної, контрольно-корекційної та ін. Процес наукової розробки та вдосконалення навчальних методів відбувається на основі новітніх досягнень у таких науках як педагогіка, психологія, лінгвістика, лінгводидактика, методика тощо.

Цікавою з точки зору стимулювання самостійної навчальної та творчої діяльності дітей $є$ програма Linoit. Цей інструмент $\epsilon$ віртуальною дошкою оголошень, яка за допомогою різноманітних шаблонів дозволяє опублікувати текст, відео та поширювати документи. Linoit може бути застосована для розміщення вказівок та інструкції для виконання завдання, а також для отримання зворотнього зв 'язку. 3 iї допомогою можна організувати творчі види робіт: розподіли, об'єднання, внесення своїх вражень тощо.

Варто звернути увагу і на програму Twiddla. Twiddla - віртуальна дошка, що призначена для спільної роботи здобувачів освіти. На ній можна розмістити текст, ілюстрацію, математичну формулу, використовуючи геометричні параметри, розробляти документи. Цядана віртуальна дошка дає можливість спілкуватися за допомогою чату та звуку.

Новим інструментом, що може бути використаний для організації спільної роботи учнів, є віртуальна дошка Miro (RealtimeBoard). Цей сервіс складається 3 набору шаблонів, що можуть допомогти у структуруванні навчального матеріалу і чудово підходить для проведення мозкового штурму. 3 його допомогою можна завантажити документ, таблицю та певні зображення, намалювати схему чи графік.

B інтерактивній дошці IDroo $є$ набір інструментів для того, щоб малювати та вводити математичні формули. Тут можна змінити колір та відкоригувати шрифт тексту, за допомогою дошки можна проводити заняття одночасно для кількох користувачів.

Таким чином, використання інтерактивного способу навчання у освітньому процесі, а саме віртуальних дошок, сприяє ефективному відбору інформаційного матеріалу та розширенню ілюстративної бази уроку, що впливає на посилення зацікавленості в учнів.

Отримання навчальних матеріалів, спілкування між суб'єктами навчання під час навчальних занять забезпечується передачею відео-, аудіо-, графічної та текстової інформації у синхронному або асинхронному режимі за допомогою додатку Zoom, на платформі додатків Google: Google meet, Google Drive, Google Classroom, додатків Вайбер, Телеграм, е-пошти [4].

Платформа Zoom - це сервіс для організації онлайн-конференцій та відеозв’язку, за допомогою якого можна організовувати конференції та веб- 
семінари для різної кількості користувачів і спікерів. Це сервіс для проведення онлайн конференцій, тренінгів та вебінарів. Викладачі використовують цей інструмент для проведення онлайн занять 3 відео високої якості через персональний комп’ютер, ноутбук, планшет чи мобільний телефон. Платформа $\epsilon$ дуже зручною для викладання, тому що дає можливість викладачу використовувати різні види завдань, які забезпечують розвиток усіх видів діяльності. Тут можна продемонструвати електронний підручник, презентацію, відео та аудіо записи тощо. Режим «Whiteboard» дає змогу викладачеві малювати та використовувати схеми для наочної демонстрації певних понять та лексики 3 теми заняття. Функція запису в даній платформі дає змогу записати онлайн заняття, щоб учасники могли, за потреби, переглянути його після завершення. Варто відзначити, що цей інструмент добре підходить для повторення граматичного матеріалу, який розглядався на онлайн занятті.

Для активного включення у навчальний процес одночасно великої кількості учасників варто звернути увагу на сервіс Google Classroom, що об'єднує в собі: Google Drive для створення і обміну завданнями, Google Docs, Sheets and Slides для написання текстів і створення презентацій, Gmail для спілкування i Google Calendar для розкладу.

Для забезпечення дистанційної взаємодії можна використати додатки: Qustion Scratchpad, Tabel Tool, Peer Assessment Tool тощо. Реалізувати дистанційну взаємодію між здобувачами освіти можна 3 використанням менш складних платформ, лише за допомогою різноманітних хмарних сервісів. Для висвітлення базових критеріїв оцінювання та надання можливості здобувачам освіти виставити бали можна використати Google Spreadsheets або Google Tabs.

Якщо оцінювання окрім балу містить ще й описову складову, можна скористатись ресурсами Google Forms або Google Docments. Для робіт творчого спрямування та із готовим продуктом можливим $\epsilon$ використання блогів (наприклад, Blogger) та віртуальних дошок (зокрема padlet.com), де здобувачі освіти мають змогу розмістити свої напрацювання та за допомогою коментарів інших користувачів здійснювати рефлексію.

Засобом для налагодження дистанційної взаємодії може бути тематичний блог. В статті «Blogging as an Innovative Method of Peer-to-Peer Educational Sharing» [5] авторами вказано на те, що ведення блогів є ефективним у сфері освіти. В дослідженнях, які було проведено, зафіксовано збільшення у дітей зацікавленості навчальним матеріалом, адже педагог може у вільній формі подавати матеріал чи створювати форум для його обговорення, також була виявлена підтримка проектів та суттєва зацікавленість у розміщених публікаціях. Дружня та професійна атмосфера, зручний доступ до ресурсів та взаємодопомога сприяють розвитку не тільки професійних якостей, а й вмінню співпрацювати, толерантно ставитись до іншої точки зору та оперативно реагувати на навчальні виклики. Оскільки українські учні, як і їх однолітки в світі, переважну більшість часу проводить 3 використанням різноманітних комп'ютерних пристроїв 3 
Журнал«Герспективита інновації науки

(Серія«Гедагогіка», Серія«Гцихологія», Серія«Медицинв»

№4(4) 2021

цілодобовим доступом до мережі Інтернет.

В результаті аналізу хмарних сервісів, за допомогою яких можна реалізувати дистанційне навчання, визначено шляхи впровадження дистанційної взаємодії з використанням: 1) форумів, чатів, зокрема в LMS Moodle; 2) автоматизації дистанційного оцінювання за допомогою ресурсу Семінар (Workshop) в LMS Moodle; 3) додатків для дистанційного оцінювання в дослідницьких навчальних просторах (Inquiry Learining Spaces - ILS), розроблених в середовищі Graasp; 4) групової взаємодії із застосуванням віртуальних дошок; 5) ведення спільного блогу; 6) додатків Google.

Використання всіх вище зазначених інструментів забезпечує всебічний розвиток дитини, адже для роботи «у класі» потрібно знати, як користуватися гуглівськими сервісами.

Сьогодні до початкової школи приходять абсолютно нові за типом мислення учні. Для них завжди існує цікавіший сайт, свіжіша інформація, вони здатні швидко «просіювати» великі обсяги матеріалу, швидко реагувати на нові повідомлення. Для таких дітей звичайні підручники здаються нудними, незручними для сприйняття інформації. Тому дуже важливо змінювати форми $\mathrm{i}$ методи, впроваджувати нові технології навчання. Це виступає необхідністю відповідати викликам часу. Тому треба створювати електронні посібники 3 відеоматеріалами, яскраві підручники 3 фотозображеннями, цікавинками, відеолекції для онлайн-курсів, використовувати QR-коди для переходу на інтернет ресурси. Особливо це актуально для дистанційного навчання, бо дозволяє не перевантажувати освітній портал великими об'ємами інформації, а учні зможуть використовувати їх в будь-який час і на будь-якій відстані, навіть із телефонів, переходити за посиланнями чи QR-кодами.

Використання QR-кодів забезпечує інтерактивну складову робочого зошита для занять, які дозволяють отримати миттєвий доступ до будь-якої інформації 3 Iнтернету за допомогою смартфонів. За QR-кодом можна переглянути рисунки, схеми, таблиці, довідковий матеріал, фотозображення, відео та інший наочний матеріал, який сформує у здобувачів освіти цілісне уявлення про об'єкти, явища та технологічні процеси виробництв, сприяє кращому запам'ятовуванню матеріалу.

Учні, навіть без електронної пошти, з мобільних телефонів можуть перейти за посиланням, надісланим в групу чи надрукованим у вигляді QR-коду, пройти тести у додатку Google Forms, переглянути свої бали і помилки, а викладач одразу отримує детальну інформацію: статистику по кожному запитанню та окремому учню, що дозволяє оперативно виявити і виправити недоліки в сприйнятті матеріалу [3].

Розглядаючи можливості для творчого розвитку учнів, варто зупинитись на інструменті, що має суттєву емоційну забарвленість, а саме на карикатурах, що мають назву «меми». Методична цінність карикатури полягає в тому, що вона створює яскравий образ, коротко резюмує суть історичного чи суспільного 
явища, події. Але слід пам'ятати, що вона може бути не об'єктивною і вимагає критичної оцінки. Враховуючи той факт, що учні початкових класів є активними користувачами соціальних мереж, що стикаються щоденно з інтернет мемами, у тому числі і на історичну тематику. Це допоможе дітям не лише краще зрозуміти минуле, а й навчить аналізувати і сучасний медіапростір.

Важливим напрямком розвитку мислення учнів під час навчання $є$ проектна робота. Уроки із застосуванням проектних технологій дають можливість суттєво активізувати розумовий та мовленнєвий розвиток дитини, покращити показники ii мислення, пам'яті, привчити бути більш уважним, спостережливим, відповідальним.

Завдяки проектній роботі в школі учні отримають можливість для успішної самореалізації. Цей вид діяльності сприяє розумінню їх власних потреб, вчить йти до мети шляхом здійснення свідомих зусиль.

Навчальне проектування не є принципово новим видом діяльності. Метод проектів запропонував і розробив американський філософ Джон Дьюї в першій половині XX ст. Ним було запропоновано побудувати навчальний процес на основі активної діяльності учнів, спираючись на цілеспрямовані дії учасників навчального процесу, щоб збільшити їх особисту зацікавленість в цих знаннях.

На даний момент, коли у вітчизняній школі виникла потреба у розробці якісно нових характеристик та напрацювань освітніх систем (потреба у зростанні поліфункціональності, цінніснодоцільності, варіативності тощо), метод проектів почав користуватися підвищеним попитом і популярністю.

Метод проектів впливає на зростання рівня розвитку пізнавального уміння i навичків здобувачів освітнього процесу, орієнтацію в інформаційному просторі, самостійне конструювання власних знань, уміння використовувати свої знання 3 інших сферах, навички критичного мислення [4].

Метод проектів зорієнтований на самостійні види діяльності дітей (індивідуальні, парні, групові вправи) у спеціально відведений для цього час (від кількох хвилин до декількох тижнів в позаурочний час, а іноді даний процес затягується на місяці).

Що стосується складності, творчі завдання слід систематично, але поступово включати в роботу. На кожному уроці важливо створити умови, в яких кожен учень може активно проявляти себе у творчості. Кожен учень повинен відчувати радість від творчості, що розвиває позитивну емоційну реакцію на реалізацію власних ініціатив.

Для того, щоб залучити учнів до навчального процесу як активних учасників, ефективним є використання програми Роvег Рoint, за допомогою якої школярі створюють презентації за результатами своєї дослідницької діяльності за змістом літературного твору, під час опрацювання характеристики героя, біографії письменника, мовних явищ. Ця ефективна форма допомагає узагальнювати, відпрацьовувати, повторювати, систематизовувати і створювати нове на основі вивченого. 
Журнал«Герспективита інновації науки

(Серія«Гедагогіка»), Серія «Гиихологія», Серія «Медицинв»

№4(4) 2021

Комп’ютерна презентація може бути використана для розвитку авторського учнівського бачення теми, розробки певного сценарію виконання i представлення аудиторії, яка, може бути абсолютно різною: від учнів початкової школи до вчителів.

Комп'ютерні технології дають можливість використовувати інформацію, представлену у мережі Інтернет, дозволяють ілюструвати, естетично оформляти власну роботу, використовувати презентації, ефекти анімації тощо. Перевагами такої роботи може бути зростання зацікавленості предметом вивчення, діти при цьому є авторами, ініціаторами нової ідеї, можуть розвивати свої інтелектуальні можливості [6].

Використання інформаційних технологій на уроках може відбуватися різними способами, метою яких є:

1) використання нових видів форми подання інформації;

2) збільшення типів навчальних завдань, що використовуються в навчальному процесі;

3) створення такого навчального середовища, яке зможе забезпечити «занурення» здобувача освіти в спеціальний, розроблений для навчання, світ, у корисні для навчання ситуації соціального та виробничого характеру;

4) постійне застосування ігрових прийомів;

5) забезпечення негайного зворотного зв'язку, можливість рефлексії;

6) можливість відтворення фрагмента навчальної діяльності.

Одним з результатів навчання і виховання в школі першого ступеня повинна стати готовність дітей до оволодіння сучасними комп'ютерними технологіями i здатність актуалізувати отриману 3 їх допомогою інформацію для подальшої самоосвіти. Для реалізації цих цілей виникає не просто необхідність застосування вчителем початкових класів інформаційних технологій в освітньому процесі, а й необхідність враховування комфортних і здоров'язбережувальних умов застосування. При врахуванні психологічних та вікових особливостей учнів початкової школи, описаних вище, можна забезпечити ефективне використання технологій освіти.

Висновки. Отже, в результаті навчання за технологіями, що розвивають творчу особистість, учні початкової школи поліпшують навчальні результати, набувають соціальних навичок, усвідомлюють позитивне ставлення до ефективної співпраці з метою розв'язання складних проблем, набувають умінь висловлювати та обговорювати власні ідеї, формулювати їх чітко і точно, позбуваються страху перед аудиторією, набувають вищої самооцінки, впевненості у власних силах, не бояться відповідальності за прийняття рішень, вчаться бачити альтернативу, часто виступають організаторами шкільних заходів, краще ставляться до навчання та школи в цілому.

Досвід роботи вчителів початкової школи з такими прийомами переконує, що такі форми проведення занять «знімають» традиційність уроку, оживляють думку, дитина навчається працювати з різними джерелами знань, при цьому не 
просто зростає зацікавленість предметами, а й розвивається творча самостійність, значно покращується успішність загального розвитку учнів початкової школи.

\section{Jimepamypa:}

1. Національна стратегія розвитку освіти в Україні на 2012-2021 роки. URL: http://oneu.edu.ua/wp-content/uploads/2017/11/nsro_1221.pdf (дата звернення: 1.11.2021).

2. Сухий О., Онопченко Г., Онопченко О. Використання засобів інформаційнокомунікаційних технологій для діагностики обдарованості дітей та молоді: методичні рекомендації. Київ: Інститут обдарованої дитини НАПН України, 2017. 52 с.

3. Збаровська Л. Розвиток творчих здібностей учнів та їх життєвих компетенцій засобами сучасних технологій: методичний посібник. Нетішин, 2020. 62 с.

4. Morze N., Vember V., Varchenko-Trotsenko L. Formative and peer assessment in high ereducation. IT tools - Good Practice of Effective Use in Education: monograph. Sc. Editor: Eugenia Smyrnova-Trybulska, University of Silesia in Katowice, Katowice, Cieszyn, 2017. P. 159-180.

5. Nedder M. M., Levine S. A., Galligan C., Avery K. R., Eagan E. Blogging as an Innovative Method of Peer-to-Peer Educational Sharing. Crit Care Nurse. 2017. № 37 (1): e1-e9. URL: https://doi.org/10.4037/ccn2017642 (дата звернення: 1.11.2021).

6. Середенко-Рожко Л. О. Методичний конкурс як інструмент професійного зростання. Професійна освіта в умовах сталого розвитку: збірник матеріалів I Міжнародної науковопрактичної конференції. м. Київ, 2016. 284 с.

\section{References:}

1. Nacionaljna strateghija rozvytku osvity v Ukrajini na 2012-2021 roky. Retrieved from http://oneu.edu.ua/wp-content/uploads/2017/11/nsro_1221.pdf [in Ukrainian].

2. Sukhyj, O., Onopchenko, Gh., Onopchenko, O. (2017). Vykorystannja zasobiv informacijnokomunikacijnykh tekhnologhij dlja diaghnostyky obdarovanosti ditej ta molodi: metodychni rekomendaciji [The use of information and communication technologies for the diagnosis of gifted children and youth]. Kyjiv: Instytut obdarovanoji dytyny NAPN Ukrajiny, 52 [in Ukrainian].

3. Zbarovsjka, L. (2020). Rozvytok tvorchykh zdibnostej uchniv ta jikh zhyttjevykh kompetencij zasobamy suchasnykh tekhnologhij: metodychnyj posibnyk. Netishyn, 2020, 62 [in Ukrainian].

4. Morze, N., Vember, V., Varchenko-Trotsenko, L. (2017). Formative and peer assessment in high ereducation. IT tools - Good Practice of Effective Use in Education: monograph. Sc. Editor: Eugenia Smyrnova-Trybulska, University of Silesia in Katowice, Katowice, Cieszyn, 159-180 [in English]

5. Nedder M. M., Levine S. A., Galligan C., Avery K. R., Eagan E. (2017). Blogging as an Innovative Method of Peer-to-Peer Educational Sharing. Crit Care Nurse, 37 (1): e1-e9. Retrieved from https://doi.org/10.4037/ccn2017642 [in English]

6. Seredenko-Rozhko, L. O. (2016). Metodychnyj konkurs jak instrument profesijnogho zrostannja. Profesijna osvita $v$ umovakh stalogho rozvytku: zbirnyk materialiv I Mizhnarodnoji naukovo-praktychnoji konferenciji - Vocational education in the conditions of sustainable development: a collection of materials of the I International scientific-practical conference. Kyjiv, 284 [in Ukrainian]. 